\title{
O efeito da cruzada neoevangélica sobre remanescentes de quilombo: questões sobre educação e identidade quilombola
}

\author{
Solange Aparecida do Nascimento* \\ Pedro Abib**
}

\begin{abstract}
Resumo
Este artigo trata da ação das religiões neopentecostais junto às comunidades quilombolas, as quais desqualificam as práticas culturais dessas comunidades. Aborda o desdobramento dessas ações no âmbito da educação e da construção da identidade quilombola. Desenvolvemos o conceito de neoevangelização pautado numa perspectiva semelhante ao projeto de catequização dos indígenas e africanos escravizados no período colonial, pelo qual os "missionários" dos dias atuais vêm utilizando o mesmo discurso de "salvar" essas populações quilombolas em várias partes do país. O recorte para análise são as comunidades quilombolas do Estado do Tocantins e a crescente presença de evangélicos nas comunidades no intuito de convertê-las. Analisamos as ações redentoras dessas missões, que historicamente se valem do discurso religioso para desarticular e desestruturar os grupos que não correspondem ao modo de vida por elas difundido.
\end{abstract}

Palavras-chave: Quilombo; Religião; Ancestralidade; Neoevangelização.

\section{The effect of cross new evangelical on the "quilombo" remaining: questions about education and identity} "quilombola"

\begin{abstract} not correspond to the way of life for them widespread.

Keywords: Quilombo; Religion; Ancestry; Neoevangelization.

Todos os dias, quando um dos nossos é agredido por "filho do capeta", nós morremos. Em cada ação arquivada nos Juizados Especiais Brasil à fora, quando juízes ou conciliadores não reconhecem a intolerância religiosa contra nossos ancestrais como violação a um direito fundamental, nós morremos. Todos os dias, quando traficantes proíbem que usemos nossos fios de contas e guias nas favelas e periferias, nós morremos. Mas, mesmo esta morte simbólica, ainda parece muito pouco. Assistimos todos os dias um dos nossos perder um emprego, sofrer uma violência verbal, ter o terreiro incendiado, perder a guarda de um filho na Justiça... tudo porque o Candomblé e a Umbanda são religiões minoritárias, que atuam sob a lógica da ancestralidade - que nos permite pensar
\end{abstract}

This article deals with the action of neo-Pentecostal religions in relation to "quilombola" communities, which disqualify the cultural practices of these communities. We discuss the deployment of these actions in education and the construction of "quilombola" identity. We developed the concept of neoevangelization in relation to a perspective similar to catechizing project of indigenous and African slaves in the colonial period, for which the " missionaries " of the present day have been using the same discourse to "save" these "quilombola" communities in various parts of the country. The corpus for analysis is the "quilombo" communities of the State of Tocantins and the growing presence of evangelical communities in order to convert them. We have analyzed the redemptive actions of these missions, which historically use religious discourse to disrupt and dismantle the groups that do

uma unicidade diversa. (...) - sabemos que as escolas expulsam nossas crianças, os hospitais não atendem nossos filhos e até mesmo nossos vizinhos se sentem incomodados com os sons dos nossos atabaques.

Marcos Rezende

Oju Oba, Casa de Oxumarê.

\section{Introdução}

É crescente nos últimos tempos as ações coercivas e violentas das igrejas neopentecostais contra as manifestações religiosas afro brasileiras. Essas ações têm se intensificado e tomado proporções cada vez mais preocupantes no sentido do desrespeito à diversidade e à livre expressão religiosa. São cada vez mais frequentes nos meios de comunicação, ataques direcionados aos povos de

\footnotetext{
*Endereço eletrônico: solangenascimento@uft.edu.br

*** Endereço eletrônico: pedrabib@gmail.com
} 
terreiros de candomblé e umbandistas, veiculados por religiosos que relacionam as entidades dessas religiões às representações demoníacas.

No desenvolvimento desse artigo, trataremos dos processos de marginalização sofrido pela população negra no Brasil, das políticas de eugenia e da criminalização das práticas culturais e religiosas dos afrodescendentes, coibidas tendo como aporte o discurso religioso, médico e jurídico.

Buscamos problematizar os efeitos das incursões religiosas e seu impacto nos aspectos da cultura e da educação das/nas comunidades. As relações que se estabelecem no âmbito das populações quilombolas diferem dos princípios norteadores da lógica ocidental e neopentecostal, dessa forma, seu legado cultural material e imaterial, sua relação com a natureza, com o místico e com a ancestralidade está ameaçada diante do discurso de demonização impetrado por essas religiões, que em um claro desrespeito à ancestralidade desses povos, classificam seus ritos e fazeres seculares como ações ligadas ao mal e ao demônio, que de acordo com seus princípios fundamentalistas, está relacionado diretamente às entidades das religiões afrobrasileiras.

Discutimos também os efeitos da descentralidade da memória e da oralidade como elementos de manutenção do legado histórico das comunidades, que diante do discurso dessas religiões, passa a ser referenciado nas escrituras (bíblia), que se torna a verdade única $\mathrm{e}$ inquestionável fonte de verdades. É importante considerar que as comunidades perpetuam suas tradições, ritos, fazeres, formas de representação e manifestações míticas a partir da oralidade, linguagem predominante na manutenção da memória e da história das comunidades tradicionais. Estas comunidades, constituídas a partir da oralidade, da memória e ações coletivas, compreendidas como mantenedoras da identidade vivenciam processos de embate na manutenção do seu território, sua identidade e sua cultura, sendo esses os elementos que as caracterizam e mais do que isso, marcam a "identidade quilombola" que tem sofrido transformações importantes diante da cruzada evangelizadora das religiões neopentecostais.

Entendemos dessa forma que os relatos orais não carregam somente os significados das vivências individuais desses sujeitos sociais, mas representam os significados e atribuições dados coletivamente por essas comunidades a cada música, cada dança, cada objeto, todo o legado simbólico material/imaterial e sua ancestralidade.
Diante da complexidade no processo de permanência do legado cultural dessas populações consideramos que os elementos da memória e da história entrecruzam o currículo da escola dessa comunidade. Cabe então pensarmos: como as narrativas locais são trabalhadas no ensino formal, que sofre hoje uma forte influência dos processos de evangelização? Quais as tramas e estratégias se desenvolvem frente a um currículo ocidentalizado na manutenção e valorização da cultura local?

\section{A construção religiosa/médico/jurídica sobre os afrodescendentes}

Em julho de 2014 foi realizado em SalvadorBA o I Seminário Internacional para Preservação do Patrimônio Cultural Compartilhado Brasil-Nigéria, no qual em seu pronunciamento o Alaafin de Oyo, Obá Ladeyemi III, considerado o descendente direto de Odudua, o fundador e primeiro ancestral do povo ioruba, expôs sua preocupação com a permanência do legado da cultura africana no Brasil.

Em seu discurso na abertura do evento, o Alaafin afirmou que em todos os países que usaram mão de obra escrava e também na África, a dominação se deu pela persuasão e pela violência. Afirma que o negro não é menos humano que qualquer outro e precisamos de nossa humanidade para sermos diferentes. Apontou também que "mesmo com a Diáspora devemos conservar nossa cultura, nossa força. Esse é o nosso compromisso: resistir. Mesmo com privações e humilhações conseguimos passar todas as dificuldades".

$\mathrm{Na}$ ocasião falou também que não há em Oyó por parte do poder público, ações de preservação da cultura Yorubá, uma vez que o muçulmanismo e o cristianismo exercem uma expressiva dominação. Em Oyó é permitido que as crianças frequentem as aulas usando o véu, entretanto as crianças de Xangó têm de cortar seus cabelos e não podem se identificar nem mesmo quando em busca de emprego: "Não há uma ação efetiva do Estado para romper com o preconceito", afirma o rei.

A realidade retratada na fala do Alaafin é recorrente em todos os países nos quais chegaram negros escravizados durante o período do tráfico negreiro. Realidades bastante parecidas serão encontradas nos países da América Latina e do Norte. Embates, lutas e resistência marcaram séculos de dominação e negação, a exemplo do mito da falsa democracia racial ou a negação da existência do negro e seu legado, seja pela desconsideração das raças em censos demográficos, seja pelo discurso da 
igualdade ou estratégias outras de camuflar a existência de africanos, como a construção do discurso da mestiçagem enquanto forma de "embranquecimento" das populações negras desses países (Munanga, 1999).

Se, durante o período colonial, o Estado e a Igreja mantiveram uma estreita relação: o padroado, a força dos senhores de engenho e da Igreja negavam e demonizavam as práticas religiosas de matriz africana, pela via da catequese ou da conversão. Mesmo após a independência de Portugal, as relações que o Estado brasileiro estabelecia com a igreja católica se mantiveram, uma vez que o catolicismo era a religião oficial no período, o que era fortalecido pelas articulações econômicas e políticas entre essas esferas. Somente no texto da Constituição de 1891, há uma clara definição quanto à laicidade do Estado e a não interveniência religiosa no governo do país, bem como o reconhecimento das religiões e seu amplo exercício, entretanto dessas orientações excetuava-se por completo as religiões de matriz africana, como nos aponta Abdias do Nascimento:

A escravidão espiritual constituía parte intrínseca da escravidão física. Tanto assim que era uma prática normal do catolicismo se associar com o tráfico e o sistema escravista, que seu proselitismo tinha o amparo dos traficantes, do Estado e da força suasória da polícia. Pode-se afirmar, assim, que o procedimento da Igreja católica e dos sacerdotes ajudou a marcar o sentimento cristão brasileiro com a indelével característica de tirania e sadismo (NASCIMENTO,1980, p.56).

Refletido num discurso corrente, utilizado para rechaçar as atuais políticas públicas para a igualdade racial; as mentalidades ainda presentes no Brasil, serviram como base para Leis e Estatutos que discriminavam os negros com forte teor racista. A exemplo disso podemos citar o Código Penal de 1890 que caracterizava como práticas criminosas: a mendicância, a capoeiragem, o espiritismo e o curandeirismo, o que foi amplamente instruído na forma de repressão à prática do Candomblé. A proibição de rodas de capoeira, de batuques e sessões nos terreiros de candomblé eram severamente punidas pela força policial por serem consideradas perturbação da ordem pública e vadiagem, vistas aí como a materialização do discurso Republicano de eugenia e as políticas de branqueamento.
O discurso racista no Brasil toma outra roupagem nos anos de 1930. Com o mito da democracia racial pautado na ideia de um país miscigenado e sem preconceitos, as tensões raciais são mascaradas e essa visão vai paulatinamente se consolidando no Brasil. A substituição do discurso do racismo científico pelo da democracia racial não muda efetivamente a situação do negro. Se, antes acreditava-se que a miscigenação degeneraria a espécie, agora a miscigenação não tem essa conotação, entretanto a exaltação da miscigenação do povo brasileiro camufla os processos de exclusão social vividos pelos afrodescendentes. Esse discurso é reforçado por Freire quando enaltece a "condescendência" e "bondade" do português em relação aos demais grupos étnicos. De acordo com o autor o "colonizador europeu foi o que melhor confraternizou com as raças chamadas inferiores. O menos cruel na relação com os escravos" (FREIRE, 1963, p. 264). Essa percepção foi e continua servindo para mascarar as tensões, conflitos, violência e o forte racismo que marca incontestavelmente as relações étnicas no país.

O uso do discurso jurídico contrário às práticas religiosas africanas esteve presente na primeira metade do século XX, entretanto se analisarmos alguns processos na atualidade, seria possível encontrarmos ainda alguns vestígios dessa forma de pensamento? Qual o lugar das manifestações religiosas afro-brasileiras hoje em nossa sociedade? Como o racismo e o preconceito tem se mostrado, e ainda, de que mecanismos de desarticulação social as comunidades negras têm sido vítimas?

No contexto atual temos alguns demarcadores que balizam nosso olhar quanto às estruturas que hoje têm ganhado espaço no que tange ao protagonismo religioso, sobretudo aquelas de caráter que chamaremos aqui de neoevangélico com forte inserção em diferentes esferas sociais e políticas. Nesse contexto, Ricardo Mariano alerta que "os ataques pentecostais desferidos contra os cultos afro-brasileiros, além de centrados em interesses expansionistas, estão imbuídos do velho ranço da ortodoxia cristã, em oposição à magia". (MARIANO, 2005, p. 71). As ações decorrentes dessa vertente religiosa muito se aproximam dos preceitos Calvinistas, que, de acordo com Weber (2008), acreditavam em sua predestinação para a salvação do mundo, o que as afastava completamente dos outros indivíduos, estes renegados ao pecado e à vida mundana. Tendo essa concepção de "escolhidos", o abismo que os separava dos outros se 
ramificava em todas as relações sociais. Ainda segundo o autor:

Essa consciência da graça divina por parte dos eleitos e santos era acompanhada de uma atitude com relação ao pecado do próximo não de compreensão baseada na consciência das próprias fraquezas, mas de ódio e de desprezo por ele por considerá-lo inimigo de Deus e portador de sinais da condenação eterna (WEBER, 2008, p. 66).

Nessa perspectiva, todos os "não eleitos" estão muito distantes do sucesso, do acesso aos bens materiais e das graças divinas às quais esse segmento tem amplo acesso. Esses preceitos assentados na teologia da prosperidade, na ideologia neopentecostal, propaga que os "escolhidos" estão destinados à prosperidade e à felicidade. Através da fé em Deus, do combate ao diabo, e dos dízimos, a retribuição divina virá na existência ainda nesta vida. Segundo esta teologia, o principal sacrifício que Deus exige de seus seguidores é de natureza financeira, ou seja, ser fiel nos dízimos e dar generosas ofertas, mas a recompensa divina também se dará por ganhos materiais (MARIANO, 2005). Aliado a essa visão está a missão de combater o mal travando uma verdadeira guerra a tudo e a todos que não professam a mesma crença.

\section{A neoevangelização}

Atualmente as religiões de matriz africana continuam em processo de luta pela preservação de suas expressões e contra o preconceito social e institucional. Pesquisa realizada pela PUC/RJ, coordenada pela historiadora e antropóloga Sonia Maria Giacomini, do Departamento de Ciências Sociais, em conjunto com lideranças do Conselho Griout, formado por 14 lideranças religiosas ligadas à Umbanda e Candomblé mostra que dos 847 terreiros de Umbanda e Candomblé identificados no Estado do Rio de Janeiro, mais da metade havia sido atacada, as ações vão desde sabotagens até agressões físicas. A pesquisa realizada em 20 meses abrangeu 30 municípios e teve como produto além do mapeamento dos terreiros o livro "Presença do axé: mapeando terreiros no Rio de Janeiro". Na obra, há relatos de 430 episódios de intolerância, dos quais apenas $15 \%$ (58 casos) levaram a ações judiciais ou denúncias formalizadas. Fiéis que tiveram o muro de suas casas pichado, que foram espancados e que tiveram atendimento médico negado por serem "macumbeiros". A pesquisadora Sonia Maria Giacomini aponta que a maioria dos atos acontece em lugares públicos, como bancos, hospitais e escolas. As agressões mais comuns são verbais. Mulheres são o principal alvo e grande parte das agressões vem de vizinhos, do sexo masculino e de orientação religiosa evangélica. $O$ discurso da demonização associado ao racismo imprime em alguns casos ações de violência e clara manifestação de intolerância.

Essas práticas alimentadas por orientações, depoimentos e testemunhos nos cultos, ampliam seu alcance por meio de programas televisivos, sites de internet, material gráfico os mais diversos, como folders, jornais, livros que exploram situações de possessão demoníaca. Em muitos casos, tendo como protagonistas "ex-pais e mães de Santo", que por intermédio dos pastores se "livram" dos malefícios causados pelos rituais que antes conduziam. De acordo com Silva esse apelo por muitas vezes tem desdobramentos, tais como:

Insuflados por essa crença, os membros das igrejas neopentecostais muitas vezes invadem terreiros visando a destruir altares, a quebrar imagens e a "exorcizar" seus frequentadores, o que geralmente termina com agressão física. No Rio de Janeiro, umbandistas do Centro Espírita Irmão Frei da Luz foram agredidos com pedradas pelos frequentadores de uma Iurd situada ao lado desse Centro (...) Uma adepta da Tenda Espírita Antônio de Angola, no bairro de Irajá, foi mantida por dois dias em cárcere privado numa igreja evangélica com o objetivo de que esta renunciasse a sua crença e se convertesse ao evangelismo (SILVA, 2007, p.12).

Essas práticas recorrentes nas igrejas neopentecostais, são tratadas por Ari Pedro Oro (2007) como religiofágicas, segundo o autor, "literalmente comedoras de outras religiões". Nessa linha de análise, Ronaldo de Almeida (1996, p.71) as intitula como religiões que procedem a "fagocitose religiosa", ou seja, reconstroem seu repertório, símbolos, ritos e crenças a partir da incorporação e ressemantização de fragmentos, de partes de outras crenças religiosas.

\section{O lugar de onde se fala: Comunidades Quilombolas do Tocantins}

O processo de controle e incorporação 
religiosa e cultural tem apresentado outros desdobramentos que discutiremos nesse artigo. Semelhante ao projeto de catequização dos indígenas e africanos escravizados no início da ocupação do Brasil pelos jesuítas, temos atualmente uma cruzada das religiões neopentecostais no intuito de "salvar" as populações quilombolas em várias partes do país. Tomaremos como recorte para análise algumas comunidades quilombolas do estado do Tocantins.

O estado de Tocantins, possui atualmente, de acordo com dados divulgados pela Fundação Palmares, 38 comunidades quilombolas certificadas, distribuídas desde a divisa com o estado do Goiás até às margens do rio Araguaia no extremo norte do estado. Todas as comunidades vivenciaram $\mathrm{e}$ vivenciam ainda uma realidade de lutas e embates pela permanência na terra, constantemente ameaçada por grileiros, latifundiários, empresas e exploradores que avançam sobre esses territórios com persuasão e uso de violência, ações essas que estão registradas em um sem número de denúncias e ações junto ao Ministério Público Federal.

Entretanto um processo tão nocivo quanto o anterior tem gradativamente se disseminando junto às comunidades, que aqui chamaremos de neoevangelização. É crescente a presença de evangélicos nas comunidades no intuito de "levar a palavra de Deus" e "afastar essas populações do pecado", entendendo que tudo o que se refere à tradição e à simbologia africana é compreendido como pecaminoso, demoníaco e inapropriado às crenças monoteístas. $\mathrm{O}$ isolamento geográfico das comunidades quilombolas, por muito tempo, permitiu os modos de produção e sobrevivência muito mais próximos da lógica e organicidade dos povos africanos do que do modelo ocidental.

A tradição que os descendentes de africanos aprenderam por meio das histórias contadas pelos mais velhos quando crianças mostra as populações africanas em pequenas comunidades onde a posse da terra era quase sempre coletiva e seguia estreitos códigos de utilização e controle por parte dos mais velhos. A lógica desse conhecimento é circular: busca o reequilíbrio constante da força vital. $\{\ldots\}$ Esse sistema cosmogônico traz uma forma de conhecer diferente da cristã (TESSEROLLI, 2006, p.75).

Essa visão cosmogônica, como norteadora das relações que se estabeleceram nas comunidades, foi um forte elemento no processo de luta e da permanência dos signos e significados construídos pelos quilombolas. A resistência nos quilombos passa pela afirmação da identidade nos fazeres, nos ritos, nos festejos, assim como pela negação desse mesmo legado como forma de defesa e preservação. Explicamos melhor: no sentido de manterem suas tradições, as comunidades as reproduzem e ressignificam nas ações do cotidiano, nos festejos, nos rituais internos, nas rezas e outras manifestações. Entretanto, em determinadas circunstâncias essas mesmas comunidades se preservam negando a existência dessas manifestações. Trata-se do princípio africano do "segredo" como fator mantenedor das tradições mais importantes de um grupo social, que só podem ser revelados aos "iniciados" (ABIB, 2005).

Esse contexto de certa forma justifica a assumência ainda hoje, por parte dessas comunidades, do catolicismo como religião oficial, sem deixar, entretanto, de fazer suas rezas, benzimentos, ritos sagrados impregnados da africanidade latente em seu convívio, em um processo sincrético dessas manifestações. Segundo Geertz:

Os sistemas simbólicos são construídos e reconstruídos o tempo todo, não são nada que se possa amarrar e dizer, é isso. Desta forma, este universo religioso africano pode ser reconstruído e atuar como um sistema de símbolos capazes de estabelecer disposições $e$ motivações nas pessoas através da formulação de conceitos (GEERTZ, 2001, p.39).

Dentre as comunidades quilombolas do Tocantins, esses processos estão imbricados em seu cotidiano, crenças e fazeres, a exemplo da comunidade Kalunga Mimoso, na qual os elementos da cultura rural, herança de seus antepassados, é percebida na forma de construção das casas, que são feitas de adobe, cobertas de palha e de chão batido, assim como a casa de produção de farinha e o paiol de milho, normalmente situado no fundo do quintal, nas trocas de produtos e mutirões na realização das lidas de campo. Essas relações também estão presentes nos batizados, nos festejos religiosos, nos trabalhos das parteiras. Com relação ao trabalho das parteiras na comunidade Maria Aparecida de Oliveira Lopes aponta:

Dona Santina, por exemplo, tornou-se 
parteira aos 16 anos de idade, através do conhecimento transmitido por sua avó, que foi parteira na comunidade Kalunga. Senhor Epifânio é reconhecido como pai-trabalho de alguns indivíduos das comunidades Mimoso e Vão do Moleque; é conhecedor dos remédios e das ervas necessárias para a terapia da parturiente ou do recém-nascido. Com essa ajuda, a parteira prepara os remédios - garrafadas necessárias na altura do parto (LOPES, 2009, p.108).

As estruturas relacionais que se realimentam continuamente nas formas de fazer e ser do povo quilombola, têm uma larga distância dos preceitos defendidos pelas religiões neopentecostais, que por sua vez têm, no sucesso e no amealhar bens materiais, um objetivo que deva ser alcançado, em uma clara alusão aos ditames capitalistas. Quanto a essa finalidade explicitada por essas religiões, Weber (2008) analisa que "desde que o ascetismo começou a remodelar o mundo e a nele se desenvolver, os bens materiais foram assumindo uma crescente $\mathrm{e}$ inexorável força sobre os homens, como nunca antes na história. (...) o capitalismo vencedor" (WEBER, 2008, p. 24).

Os princípios das religiões neopentecostalistas "capitalizam" as relações, não só religiosas, mas todas as relações do cotidiano em nome de uma ideia de vencer em nome de Deus, ou seja, o sucesso pautado no consumo e na aquisição de posses garante o sucesso e a benção de Deus. Essa lógica é totalmente antagônica às formas de vida coletiva das comunidades quilombolas, e às suas perspectivas de bem viver, ser e relacionar-se.

Essa "capitalização" das relações e a perda da identificação das comunidades a partir das investidas dessas religiões, pode ser exemplificada pela realidade da Comunidade Mumbuca, que se constitui como uma comunidade evangélica. Os anciãos contam que seus antepassados eram católicos e que começaram a sofrer influências religiosas a partir de missões evangélicas dirigidas por norteamericanos, os batistas, já nos anos de 1970, quando a maior parte da comunidade se filiou à Assembleia de Deus. Quanto a esse fenômeno Antônio Liberac Cardoso Pires (2006) aponta que atualmente na comunidade, com o processo de evangelização, diversas práticas lúdicas que eram realizadas foram abandonadas. Essas mesmas práticas podem ainda ser encontradas "em outras comunidades da região do Jalapão que não apresentam fortes traços de evangelização" (2006, p. 75).
Vale destacar que aquilo que é tratado como "práticas lúdicas" representam mais do que isso, tratam-se das referências da comunidade acerca de sua origem, dos ritos e simbologias que as conecta com o passado-presente-ancestralidade. $\mathrm{O}$ abandono de suas práticas e crenças está relacionada:

A estrita alienação do mundo, ou seja, de toda relação desnecessária com pessoas leigas, juntamente com a mais estrita bibliocracia, no sentido de se tomar a vida das primeiras gerações de cristãos como modelo, foram o resultado para as primeiras comunidades batistas, e esse princípio de alienação do mundo nunca desapareceu (WEBER, 2008, p.79).

Ainda ilustrando a riqueza de elementos culturais que compõem essas comunidades, podemos citar a Comunidade Quilombola Lagoa da Pedra, situada no município de Arraias, sul do Tocantins que mantêm manifestações culturais como a Folia de Reis, Festas Juninas, Roda de São Gonçalo, Rezas de Ladainhas, Festa dos Mascarados e a Malhação do Judas. São práticas na comunidade também o uso de ervas para os mais variados fins, principalmente os medicinais, bem como para benzimentos e confecção de breves e patuás.

No ano de 2008 desenvolvemos uma atividade de campo nas disciplinas de Metodologia da História e História e Cultura afro-brasileira com acadêmicos do curso de Pedagogia da Universidade Federal do Tocantins. Nessa atividade foi realizado o levantamento socioeconômico dos moradores da comunidade, bem como a proposição de uma intervenção pedagógica com as crianças dos primeiros anos do ensino fundamental. Durante o trabalho, a professora dos anos iniciais fez um relato sobre uma situação que vem preocupando os moradores, em especial os mais velhos: segundo ela, na comunidade ninguém mais confecciona os instrumentos tocados nos festejos, e os mais jovens ainda não sabem tocá-los.

Dentre alguns dos fatores que colaboram para a não confecção dos instrumentos está o fato de que algumas pessoas da comunidade que dominavam as técnicas de confecção, uma vez que haviam se convertido às religiões evangélicas, não mais participavam das manifestações culturais, tão pouco construíam os instrumentos de percussão, considerados por esses agora representações do mal.

O processo de negação cultural do negro teve reflexos nos processos de construção identitária, 
solapando a expressão linguística, musical e religiosa. Meyer (2005) aborda o papel de diferentes formas de racismo, nacionalismo e etnocentrismo que em conjunto com discursos sobre classe, gênero, sexualidade, geração e religião produzem diferentes estereótipos e práticas, as quais alavancam tanto projetos políticos oficiais quanto a cultura popular, ainda de acordo com o autor, "essas formas de racismo têm também que coexistir e se articular continuamente com uma variedade de discursos e práticas em torno da meritocracia, oportunidades iguais e direitos do cidadão e por isso são extremamente complexas, ambíguas, escorregadias e conflituosas" (p. 38 ).

Quando lançamos nosso olhar à escola e suas bases é importante observar como se dá o processo de civilização. Negar a existência das raízes afrodescendentes é de certa forma alavancar um discurso único que constrói laboriosamente representações, comportamentos e atribuição de significados, criando assim um ambiente de homogeneidade do pensamento religioso no espaço que legalmente é destinado a garantir a diversidade, a escola. A construção de significados segundo Bujes (2000, p. 25)

[...] não resultam [...] de um processo de evolução, nem estão acima e à parte das divisões sociais, sexuais, raciais, étnicas...São modelados no interior de relações de poder e representam interesses manifestos da Igreja, do Estado, da Sociedade Civil [...] implicam intervenções da filantropia, da religião, da Medicina, da Psicologia, do Serviço Social, das famílias, da Pedagogia , da mídia [...] Contudo, esses significados não são estáveis nem únicos, $e$ as linguagens que usamos, ao mudar constantemente, são indicativas da fluidez $e$ da mutabilidade a que estão os sujeitos. $O$ espaço escolar agrega diferentes culturas, $o$ que supõe o preparo e a competência para trabalhar com as várias vertentes religiosas.

De acordo com Pantoja, (2006) o estudo da História da África não se reduz ao estudo da escravidão, seria reduzir a um pequeno espaço de tempo, aproximadamente três séculos, a história milenar de um Continente, bem como todo seu legado histórico, cultural e religioso.

Esse contexto de certa forma circunscreve a abordagem que trazemos aqui: Qual o impacto do movimento das religiões neopentecostais junto às comunidades tradicionais afrodescendentes? Existe um respeito à ritualidade dessas comunidades? Qual o sentido dessa ressignificação de identidades para os membros "convertidos" da comunidade? O que significa não fazer mais parte dessas manifestações? Quais os impactos dessa intervenção nos espaços educativos formais e não-formais da comunidade? Esses e outros questionamentos se fazem necessários caso queiramos nos debruçar sobre o tema e realmente entender sobre quais circunstâncias esses processos de desenrolam.

A situação descrita na Comunidade da Lagoa da Pedra não se caracteriza como caso isolado. Temos observado cada vez mais, pastores em visitas domiciliares dentro das comunidades, promovendo reuniões e impetrando forte interferência em seu cotidiano, o que se aplica não somente às manifestações religiosas, mas em todas as relações que se estabelecem nas comunidades, desde as familiares até às relações de trabalho, uma vez que essas religiões têm como princípio "um repúdio sincero do mundo, de seus interesses e uma submissão incondicional a Deus". (WEBER, 2008, p.81) $\mathrm{O}$ que apontamos aqui como ameaça às comunidades, são justamente as ações civilizatórias dessas missões que historicamente se valem do discurso religioso para desarticular e desestruturar os grupos que não correspondem ao modo de vida por elas representado. As comunidades quilombolas mantêm elementos seculares da cultura africana, o que podemos perceber na relação com a terra, as matas e florestas, na ritualização presente no abate de animais, no plantio, nas canções de trabalho, no uso de ervas para diferentes fins, na tradição oral.

$\mathrm{O}$ discurso neopentecostal ataca diretamente o povo africano e afrodescendente atribuindo a seus cultos e crenças a conotação antagônica de bom/mau, divino/satânico, civilizado/selvagem. É presente ainda em diferentes esferas sociais o preconceito e a discriminação contra essas manifestações. O que está em questão além do direito ao exercício pleno da religiosidade africana, é também a valorização de sua constituição histórica e seu legado material e imaterial. De acordo com Pollak: "se é possível, o confronto entre a memória individual e a memória dos outros, isso mostra que a memória e a identidade são valores disputados em conflitos sociais e intergrupais, e particularmente em conflitos que opõem grupos políticos diversos" (POLLAK,1992, p.13).

Os ataques desferidos contra as comunidades afro-brasileiras agem diretamente sobre a construção da memória social e da história dessas populações, 
mas que mesmo diante desse forte aparato ideológico, têm encontrado formas particulares de resistência.

\section{Identidade quilombola e o olhar do outro}

Aquilo no que se acredita se materializa no cotidiano de um grupo social, e portanto, a negação dessa crença implica na não permanência dos fazeres tradicionais perpetrados naquele território, e ainda assinala a ruptura desses fazeres na comunidade com suas relações mais fortes de ancestralidade. Se antes a palavra falada, a história oral tinha o papel de difundir seus conhecimentos, a implementação do discurso de que a verdade agora é o que está escrito no "livro sagrado", qual o valor que é atribuído então à ancestralidade e o saber dos mais velhos? De acordo com Bhabha (2013) a tradição oral como manifestação da tradição cultural:

"...encerra um conjunto de significados que se apresentam com continuidade $e$ constância entre membros de um grupo étnico-racial. Encontram-se tais significados inscritos intenções, projetos, posicionamentos, avaliações, articulados no agir e intervir no ambiente. Trata-se de patrimônio ancestral inatingível que sobrevive com renovados contornos, como que ocultados, mas sempre compartilhados" (BHABHA, 2013, p. 59).

De fato, podemos inferir que boa parte das religiões neopentecostais sofrem influência de valores fundamentalistas vindos de uma tradição religiosa norte americana de princípios conservadores. De acordo com Castells o fundamentalismo está muito mais relacionado a processos políticos de defesa política de valores morais e cristãos do que a uma racionalização dos conceitos de classe ou território. Ainda de acordo com o autor "trata-se de um movimento reativo, voltado a construção da identidade social e pessoal" (CASTELLS, 1999, p .42).

É aí que se encontra o ponto nevrálgico da questão: como coabitam nas comunidades quilombolas diferentes identidades pessoais e sociais? O discurso reificado por esses representantes religiosos de alguma forma considera as identidades ali construídas secularmente? Ou diferente disso impõe seus valores bíblicos e cristãos como a nova ordem a ser seguida? Segundo Hall: "as identidades são fabricadas por meio da marcação da diferença. Essa marcação da diferença ocorre tanto por meio de sistemas simbólicos de representação quanto por meio de exclusão social. A identidade pois não é o oposto da diferença, a identidade depende da diferença. Nas relações sociais essas formas de diferença - a simbólica e a social são estabelecidas, ao menos em parte, por meio de sistemas classificatórios" (2012, p.79).

As marcações simbólicas e sociais nas comunidades sofrem um grande revés frente aos valores reificados pelas religiões evangélicas, dessa forma constrói-se em um mesmo território a diferença entre os "escolhidos" e os "não escolhidos", os "puros" e os "impuros", institui-se dessa forma, a diferença entre aqueles que sempre se viram como iguais.

No processo da Diáspora africana homens e mulheres negros foram obrigados a se adaptar a uma nova sociedade; os africanos não podiam manter seus próprios cultos, com isso eles recriavam e integravam ritos e símbolos católicos, reafirmando assim sua identidade africana. Segundo Apolinário (2006, p. 136), "mesmo sob o poder disciplinar dos senhores, os negros se organizavam em irmandades, reconstruindo a religiosidade africana nas brechas do catolicismo". Cabe aqui repensar como se dá a compreensão da identidade religiosa e da diversidade cultural a partir dessa forma de resistência. De acordo com Hall (2012, p.38), a identidade é "realmente algo formado, ao longo do tempo, através de processos inconscientes, e não algo inato, existente na consciência no momento do nascimento". Ainda de acordo com o autor (p.39) "...em vez de falar da identidade como uma coisa acabada, deveríamos falar de identificação, e vê-la como um processo em andamento".

Entendemos que neste processo de identificação a escola não se constitui espaço de neutralidade quando se refere às escolhas epistemológicas e curriculares. Costa (2005) enfatiza que tanto as escolas quanto os currículos constituemse como territórios de produção, circulação e consolidação de significados, compreendendo espaços privilegiados na concretização de políticas de identidade. A questão que se apresenta é como esses espaços podem garantir a produção de significados positivos da cultura local. Nesse sentido Costa (2007, p.41) compreende o currículo e seus componentes como um "conjunto articulado e 
normatizado de saberes, regidos por uma determinada ordem, estabelecida em uma arena em que estão em luta representações, narrativas, significados sobre as coisas e seres do mundo."

Pensemos então sobre quais narrativas são validadas no espaço escolar? Que significados estão sendo construídos acerca da identidade e da religiosidade das populações quilombolas? Que representações estas crianças e jovens têm produzido acerca da cosmovisão africana e dos cânones religiosos ortodoxos? Essas são questões que nos renderiam uma profícua discussão, considerando que o currículo assumido na escola reflete e é refletido fora dela. Lopes (2002) pondera que:

A educação é crucial na construção de quem somos. Isso quer dizer que os significados construídos na escola sobre a vida social, paralelamente a outros significados a que somos expostos em outras práticas discursivas das quais participamos, desempenha papel central na legitimação das identidades sociais. É na escola, porém, que as crianças, em geral, se expõem, pela primeira vez, a significados que podem contestar ou confirmar quem elas são com base em como suas identidades foram construídas na família (LOPES, 2002, p.59).

A educação é crucial na construção de quem somos. Isso quer dizer que os significados construídos na escola sobre a vida social, paralelamente a outros significados a que somos expostos em outras práticas discursivas das quais participamos, desempenha papel central na legitimação das identidades sociais. É na escola, porém, que as crianças, em geral, se expõem, pela primeira vez, a significados que podem contestar ou confirmar quem elas são com base em como suas identidades foram construídas na família. (LOPES, 2002, p.59).

Dessa forma, considerando as práticas catequizadoras das igrejas neopentecostais, como estão se construindo os discursos sobre as práticas culturais e religiosas das comunidades? Os significados que são construídos nesse caso interferem em sua percepção e consequentemente na contestação ou afirmação de sua origem. No que se refere à diversidade étnico racial e às comunidades quilombolas podemos citar a Resolução $\mathrm{N}^{\circ} 8$, de 20 de novembro de 2012 que apresenta as diretrizes para a educação escolar quilombola na Educação Básica, o documento orienta que a abordagem do ensino se dê:
"[...] fundamentando-se, informando-se $e$ alimentando-se: a) da memória coletiva; $b$ ) das línguas reminiscentes; c) dos marcos civilizatórios; d) das práticas culturais; e) das tecnologias e formas de produção do trabalho; f) dos acervos e repertórios orais; g) dos festejos, usos, tradições e demais elementos que conformam o patrimônio cultural das comunidades quilombolas de todo o pais; h) da territorialidade".

Ora, quando analisamos a Resolução é inegável que o que estrutura e sustenta as comunidades quilombolas é contraposto fortemente pelo discurso evangélico que nega e demoniza violentamente os elementos circunscritos à memória, à língua, aos marcos civilizatório, às práticas culturais, aos acervos e repertórios orais, aos festejos, usos, tradições e demais elementos que conformam o patrimônio cultural das comunidades quilombolas.

Esses processos educativos são, junto às conversas ao pé do fogão à lenha, da escuta atenta dos "causos" dos antigos, os mantenedores da tradição, da história e da memória da comunidade. A comunidade como um todo é responsável pela transmissão dos conhecimentos, dos fazeres e dos processos de lutas e conquistas empreendidos em sua trajetória.

Em contraposição aos balizadores legais é apresentado às crianças na escola um mundo em que os padrões eurocêntricos são tidos como valores reificados e superiores aos demais povos, os discursos sobre a produção humana, seja ela tecnológica, artístico-cultural, religiosa ou científica, via de regra, remete aos grandes feitos e descobertas europeias descartando uma miríade de conhecimentos ancestrais produzidos pelos povos africanos. Em conferência realizada na Universidade Federal da Bahia em 2014 o professor Kabengele Munanga dizia que:

O primeiro fator constitutivo da identidade é a história. No entanto mal a conhecemos pois ela é contada do ponto de vista "do outro", de maneira negativa e depreciativa. É essencial reencontrar o fio condutor da verdadeira história do negro, que o liga à África sem distorções e sem falsificações.

Essas distorções a que se refere Munanga estão nos currículos, nos discursos e nos materiais didáticos que disseminam permanentemente em crianças e jovens negros uma história de 
invisibilidade dos elementos constitutivos de sua própria identidade. Nesse sentido a construção de outros significados passa por "uma política de desreificação, de desconstrução desses conceitos na prática cotidiana" (Macedo, 2005, p.88).

A partir desse entendimento, cabe considerar toda diversidade e complexidade da construção identitária da criança no espaço escolar, o que depende, entre outros elementos da percepção histórica do educador, da construção de um currículo e de práticas que tenham como mote o respeite à diversidade e â construção de um espaço de protagonismo de diferentes crenças, vivências e histórias.

Ora se entendermos a construção da identidade como algo que se dá em processo e vai-se construindo paulatinamente, como pensar no trânsito de outras referências religiosas em espaços fecundos na disseminação de elementos apresentados como verdades absolutas e únicas para as crianças? Os discursos religiosos aparecem desconsiderando todo o legado sócio cultural das comunidades, independentemente de suas origens étnicas e culturais. Aqui apontamos os regimes de verdade dominantes, e o processo de naturalização de uma concepção de religiosidade, cabe ainda salientar que esse processo não só constrói uma representação de religiosidade bem como define as bases em que estabelecem as relações inter e intrapessoal, os discursos se configuram aí como instrumentos e estratégias de regulação e controle, além do que desresponsabilizam o sujeito de gerenciar sua vida e suas escolhas, uma vez que as mudanças e decisões são atribuídas a outrém que deverá fazer, escolher e gerenciar a vida dos sujeitos.

$\mathrm{O}$ que abordamos aqui é que, mesmo naqueles territórios quilombolas em que esses sujeitos não se percebam/declarem como candomblecistas ou umbandistas, a religiosidade ali presente se expressa por outros ritos e símbolos. De acordo com Munanga (2012):

A cultura, herança coletiva da sociedade, é o conjunto de objetos materiais que permite ao grupo assegurar a vida cotidiana, de instituições que coordenam as atividades dos membros do grupo, de representações coletivas que constituem uma concepção do mundo, uma moral, uma arte (MUNANGA, 2012, p.156).

Os balizadores de ancestralidade referentes às vivências nas comunidades, a exemplo dos objetos, hábitos, costumes, canções, rituais, mitos, modos de produção e demais elementos levantados pelo autor e que permeiam seu cotidiano, não encontram lugar na lógica produtivista e reacionária das religiões neopentecostais, nas quais a relação com o trabalho está diretamente ligada ao sucesso pessoal. A ritualização do cotidiano é vista como fraqueza moral, a arte como manifestação demoníaca, procedimentos intelectuais condenados como entrega às coisas mundanas, ou seja, o arcabouço e as bases sócio afetivas das comunidades são vistas como "manifestação de um comportamento irracional e sem objetivo, e, portanto, não agradável a Deus" (WEBER, 2008, p.9).

A base que pauta esse discurso muito se aproxima de outros episódios de luta e resistência das comunidades afro-brasileiras, perseguidas por quatro séculos pela Igreja Católica no período colonial, submetidas ao discurso médico e jurídico do período republicano e suas políticas de eugenia e branqueamento, assim como as práticas excludentes das elites tradicionais e racistas que classificam essas manifestações culturais e religiosas como exóticas e folclóricas. Entretanto é inquestionável, que à medida que as religiões neopentecostais vêm ganhando espaço midiático, político e institucional, há deliberadamente um ataque intensivo no sentido de abafar completamente as manifestações culturais religiosas dos povos de terreiro e demais comunidades afro-brasileiras, seja a partir do discurso ou do uso da força. Instaura-se em pleno século XXI um novo episódio das Cruzadas e da Inquisição no Brasil.

\section{Referências}

ABIB, P. R. J. Capoeira Angola: Cultura Popular e o Jogo dos Saberes na Roda. CMUUnicamp/EDUFBA. Campinas/Salvador, 2005.

ALMEIDA, R. de. A Universalização do reino de Deus. 1996, 127p. Dissertação (Mestrado em Educação). Faculdade de Educação. Universidade Estadual de Campinas.

APOLINÁRIO, J. R. Escravidão Negra no Tocantins Colonial: vivências escravistas em Arraias. (1739 - 1800). Goiânia: Kelps, 2006.

BRASIL. Ministério da Educação. Diretrizes 
curriculares nacionais gerais da Educação Básica. MEC/SEB/SECADI, 2013.

BHABHA, H. O Local da Cultura. $4^{\text {a }}$ Ed. Belo Horizonte: Editora UFM, 2013.

BUJES, M. I. E. O fio e a trama: as crianças nas malhas do poder. Educação e Realidade, v. 25, n. 1, p. 25-44, jan./jun. 2000.

CASTELLS, M. O Poder da Identidade. A era da informação: economia, sociedade e cultura. $5^{\text {a }}$ Edição. São Paulo: Paz e Terra, 1999.

COSTA, M. V. Currículo e política cultural. In: COSTA, M. V. (org.). O currículo nos limiares do contemporâneo. Rio de Janeiro: DP\&A, p.37-67, 2007.

FREIRE, G. Casa grande senzala. Brasília: Editora UnB, 1963.

GEERTZ, Clifford. Nova luz sobre a antropologia. Rio de Janeiro: Zahar, 2001.

HALL, S. Quem Precisa de Identidade? In: SILVA, T. T. (Org.). Identidade e diferença: a perspectiva dos estudos culturais. Petrópolis: Vozes, 2012, p. 103-133.

LOPES, L. P. M. Identidades Fragmentadas: a construção discursiva de raça, gênero e sexualidade em sala de aula. Campinas, SP: Mercado das Letras, 2002.

LOPES, M. A. O. Experiências históricas dos quilombolas no Tocantins: organização, resistência e identidades. UNESP - FCLAs - CEDAP, v. 5, n.1, p. 99-118 - out. 2009.

MACEDO, R. S. Chrysallís: Currículo e Complexidade: a perspectiva crítico-multireferencial e o currículo contemporâneo. Salvador: EDUFBA, 2005.

MARIANO. R. Neopentecostais: sociologia do novo pentecostalismo no Brasil. São Paulo: Loyola, 2005.
MEYER, D. E. Etnia, raça e nação: o currículo e a construção de fronteiras e posições sociais. In: COSTA, M. V. (Org.). O currículo nos limiares do contemporâneo. $4^{\mathrm{a}}$. edição. Rio de Janeiro: DP\&A, 2005, p. 69-83.

MUNANGA, K. Rediscutindo a mestiçagem no Brasil: identidade nacional versus identidade negra. Petrópolis, RJ: Vozes, 1999.

Negritude: usos e sentidos. Belo Horizonte: Autêntica, 2012.

NASCIMENTO, A. O Quilombismo. Petrópolis, RJ: Vozes, 1980.

ORO, A. P. Intolerância Religiosa Iurdiana e reações afro no Rio Grande do Sul. In: SILVA, V. G. Intolerância Religiosa: impactos do neopentecostalismo no campo religioso afrobrasileiro. São Paulo: EDUSP, 2007.

PANTOJA, S. A. África imaginária e a África real. In: PIRES, A. L. C. Sociabilidades Negras: comunidades remanescentes, escravidão e cultura. Belo Horizonte: Daliana. 2006, p. 22-23.

POLLAK, M. Memória e Identidade Social. Estudos Históricos. Rio de Janeiro, vol. 5, n. 10, 1992, p. 200212.

PIRES, A. L. C. (Org). Sociabilidades negras: Comunidades remanescentes, escravidão e cultura. A. L. C. Belo Horizonte: Daliana, 2006.

SILVA, V. G. Intolerância Religiosa: impactos do neopentecostalismo no campo religioso afrobrasileiro. São Paulo: EDUSP, 2007.

TESSEROLLI, M. A Festa de Seu Zé Raimundo de Pai Brasil. Seminário Internacional - Amazônia e Fronteiras do Conhecimento. Belém. 2008, p. 1-13.

WEBER, M. A Ética Protestante e o Espírito do Capitalismo. $2^{\text {a }}$ Edição revisada. São Paulo: Céngage Learning, 2008.

\section{Sobre os autores}

Solange Aparecida do Nascimento: Doutoranda em Educação pela Universidade Federal da Bahia, participante do Grupo de Pesquisa Griô: culturas populares, ancestralidade africana e educação. Com experiência em Educação 
desenvolve pesquisas na área de identidade, cultura e territorialidade das comunidades quilombolas no Estado do Tocantins.

Pedro Abib: Pós-Doutor em Estudos Lusófonos pela Universidade Nanterre La Defense-Paris X, professor da PósGraduação na UFBA tem experiência na área de Educação, com ênfase em Identidade e Cultura, atuando principalmente nos temas: capoeira, samba, cultura popular, memória, identidade, arte-educação e educação nãoformal.

Recebido em setembro de 2015.

Aprovado em abril de 2016. 